Sexing the Colorlines: Black Sexualities, Popular Culture, and Cultural Production

\title{
Finding the Humanity in Horror: Black Women's Identity in Fighting the Supernatural
}

\section{Kinitra Brooks}

Department of English, University of Texas at San

Antonio, San Antonio, TX USA

"Not only will I stare. I want my look to change reality." -bell hooks

In her article, "The Oppositional Gaze: Black Female Spectators" bell hooks posits the existence of an oppositional gaze possessed by black women in the realm of film theory. ${ }^{1}$ This theory is in contrast to the filmic theory of the white male gaze, which aggressively penetrates the image of the passive white female upon the screen. ${ }^{2}$ hooks insists that black women have much to offer film theory for they occupy a unique position, neither possessing the penetrative power of the phallic gaze nor the passivity allowed the construction of white womanhood, their gaze may exist as oppositional to both constructions (hooks 57). Yet, I suggest that this oppositional gaze has the ability to go far beyond the realm of film. Black women writers, popularized in their literary Renaissance of the 70s and 80s, have occupied this oppositional gaze within the written format.

The writers that most pique my critical interests, Tananarive Due and L.A. Banks, continue this tradition of the oppositional gaze within speculative horror fiction. Speculative fiction operates as a catchall term for science fiction and fantasy fiction that includes such themes as horror, supernatural, apocalyptic, and dystopian/utopian fiction. These texts privilege the reclamation of the black woman's body. The black female body in these books demonstrates a power that allows for personal explorations of pleasure and pain and the possibilities for socio-political change within the black community. For Octavia Butler insists that "science fiction is not about the problems of the world, but also about solving the problems of the world (Pough ix). ${ }^{3}$ These women are staring back at the genre of 
vampire fiction through the medium of print. They are talking back and changing their own reality with the agency of words in a surreal world.

In this piece, I wish to further Gwendolyn Pough's exploration articulated in the groundbreaking issue of FEMSPEC focused on black women's speculative writing. I posit that Banks and Due "rewrite, re-visit and re-envision history in ways that connect them to black women's legacies of struggle" (Pough and Hood). L.A. Banks has created a speculative world of vampires, slayers, shifters, angels and demons in her twelve-volume Vampire Huntress Legend series. The novels center on the protagonist Damali Richards, a spoken word artist and Millenium Neteru (Banks' term for the divinely chosen vampire hunter) and her boyfriend/lover/vampire antagonist/divine partner Carlos Rivera. Tananarive Due pushes the boundaries of Christianity, blood cults, and goddess worship in her African Immortals series. The trilogy examines the adventures of Jessica Jacobs-Wolde and her husband, the Immortal, Davit (or David) Wolde, and their daughter, the goddess-like, Fana.

Pough believes that "Black women have been writing speculative visions of the world for some time. Black women have in a sense always had to speculate and envision other ways of being, other ways the world can be" (Pough 165). I contend that Tananarive Due and L.A. Banks rewrite and revamp history by focusing on black women's bodies as sites of reality-changing power, and that their characters occupy multiple positions as complexly constructed lovers, and as both protector and protected. Speculative fiction allows Banks and Due to explore the complexities of their female protagonists in a lengthy format, a series of written novels. Ultimately, these authors employ the oppositional gaze in order to articulate the complexities of black women by constructing their characters in fantastical speculative worlds.

The journeys of Damali Richards and Jessica JacobsWolde privilege the idea that their personal growth as individual women and work as community leaders stand as an example of the struggle to achieve balance. Both women serve their communities without sacrificing their own agency and individual worth. Banks and Due illustrate how the growth of the personal self aids the political, for it is only when their characters come into their own as women/sisters/daughters/wives/mothers/lovers that make up their multi-faceted identities that they truly begin to aid the community at large. This is a direct assault on 
the stereotypical, harmful, and reductionist stereotype of the strongblackwoman who sacrifices their personal self and their vulnerability for the gain of the black community (Morgan).

What remains dynamic about this literature is that these women are re-writing the often fossilized genre of vampire fiction, a genre that revels in that which is dead, rotten, and abject (Hutchings). Yet, this reimagining of the vampire lore makes a specific sort of sense. The realm of horror often blurs the binaries that define Western culture, those between living/dead, good/evil, natural/supernatural, normal/ abnormal sexual desire, and masculine/feminine (Creed; Clover). No figure of horror embodies this blurring of the lines like the vampire. The vampire is a living corpse who subsists off of the religiously loaded elixir of blood whose desirability factor ameliorates the socially taboo act of necrophilia. Black women writers of the horror fiction genre seize the opportunity to continue to act as shifting signifiers who worry the lines Western society has used to contain their images (Wall; Boyce-Davies).

Tananarive Due rewrites the vampire in her construction of Jessica Jacobs-Wolde, who is an immortal with special blood, that is, the living blood of Jesus Christ, which prevents her from dying. Her husband, David, one of the original Immortals, converted Jessica. Though he does not feed on the blood of others, he is certainly constructed as feeding upon their very humanity for he continuously kills the innocent to protect his secrets. There has been a long-standing edict against the sharing of the living blood with women, a ban her husband David specifically disobeys (Due My Soul to Keep). The Community of Immortals keeps the secret of Christ's blood to themselves, sharing it with a privileged few, who are all male. The discovery of Jessica and Fana's existence sends the Seekers on a murderous mission to find them (Due The Living Blood). In The Living Blood Jessica lives in hiding with her physician sister, Alexis, in Botswana and her toddler daughter, Fana. Jessica's experience in Botswana centers on the shifting and often conflicting roles of mother, sister and wife [in absentia] and how she must deal with the growing supernatural realities in her life. Fana, conceived by two immortals, is different and Jessica realizes she is not equipped to deal with her daughter's growing powers even as her gender continues to separate her from the colony of men who control the living blood. In the midst of this life chaos, Jessica transforms her forced exile into an exploration of her own agency as she realizes 
the magnitude of the gift of life she has acquired. For she and her sister begin to secretly use the power of the living blood to heal sick children of rural Botswana (Due The Living Blood).

Banks, like Due, revives the rich genre of vampire horror fiction while exploring the themes of black women's wish to aid their larger communities. Damali Richards is a spoken-word artist who raps her poetry over a fusion of rock and hip-hop. She is also the Millennium Neteru: a chosen Vampire huntress with special weapons and powers guided by her earthly Mother-seer, Marlene Stone, and a cosmic council of former Neteru Queens. Damali is supported in her quest against vampires and other supernatural beings, by her background band who are also her chosen guardians, outfitted with special powers to enhance their fighting in the protection of the Neteru (Banks The Awakening). All of Damali's special powers are used to protect and cleanse first her immediate community and, later, the world at large from the blight and infection of demonic and vampiric evil that permeates society. Though the Neteru exists to save the world, Damali better mobilizes her powers as she understands herself, her beliefs, and her place in the world. She is a general at war with the evil of the world, fighting against Vampire Master Fallon Nuit, a corrupted vampiric Neteru, the head of the Vampire Council, Cain, Lilith, and eventually Lucifer himself (Banks The Damned).

The vampire has long been associated with different manifestations of human sexuality. The sexuality of the original vampire, Dracula, displays a sexuality that possesses a certain sense of the uncanny. It is a sexuality that is alien yet eerily familiar, "it initially looks strange but quite often presents a distorted image of human tendencies and behavior" (Stevenson 142). One of the most interesting facets of vampirism is the astonishing ability to eat and reproduce through the action of the bite. In the bite, there is a conflation of blood and semen. Critic John Allen Stevenson examines the active privileging of blood in the Dracula story: "it is food, it is semen, it is a rather ghastly parody of the Eucharist, the blood of Christ that guarantees life eternal (Stevenson 144).

Still, the most interesting characteristic of the primary vampire myth is Dracula's ability to examine the peculiarities of human sexuality by complicating the sexual constructions of women and racial others. Blood continues to be privileged in the vampire myth as a noted racial signifier of otherness. It is Dracula's foreign blood as a 
pure vampire "whose very strangeness renders him monstrous, and more dangerous, he is an imperialist whose invasion seeks a specifically sexual conquest; he is a man who will take other men's women away and make them his own" (Stevenson 144). Stevenson's reading of Dracula proves most interesting, for he reads the plot as a sexual potency competition by a group of males defending their women from conquest by a foreign other. For Stevenson reads Dracula's bite as not only a sexual seduction, but also as an act of physical "deracination" that "re-creates them as members of his own kind" (Stevenson 144). Their conversion to vampires through Dracula's bite creates a new racial identity that produces new loyalties apart from those of the original groups. For it is "that loss of women's loyalty that the good, brave men cannot abide" (Stevenson 144). The patriarchal fighting over the sexual and racial identity of the women in Dracula also subsumes women's ownership of their sexual selves. Stevenson notes that Dracula has a "hostile history" regarding female sexuality because there is a focus on men's release of and control over the women's desires. Yet, Stevenson reads Dracula's treatment of women as much more complicated. Their conversion into vampires breaks through the tired virgin/whore dichotomy that defines Western womanhood. They become something entirely different even as their conversion is instigated by a foreign male figure.

Due and Banks recognize the complicated constructions of racialized and gendered sexuality that intersect in the vampire myth and capitalize on the potentials of these intersections to create and expand a reimagining of black female sexuality. There certainly exists a dearth of black females defining and naming their own sexualities. Black female sexuality has rarely been treated with nuance; there has been a history of either extreme exaggeration as an excuse for the hegemonic horrors perpetrated since slavery or a punishing silence supported by the black middle class (Hammonds). Critic Hortense Spillers speaks of the black woman as "the beached whales of the sexual universe, unvoiced, misseen, not doing awaiting their verb" (Spillers 74). Evelyn Hammonds' Black (W)holes and the Geometry of Black Female Sexuality remains one of the most groundbreaking articles analyzing black female sexuality. In the article, Hammonds historicizes and contextualizes black female sexuality all while calling for more explicit yet nuanced expressions of black female sexuality in its myriad forms. I contend that Banks and Due reinterpret the vampire myth 
to explicitly and enthusiastically enter the contemporary conversations surrounding black female sexuality initiated by Hammonds' article. Banks and Due render black female sexuality visible by engaging in what Hammonds terms the "politics of articulation."

LA Banks and Tananarive Due repeatedly explore the sexual cravings and experiences of their respective central characters, Damali Richards and Jessica Jacobs-Wolde, rendering this particular facet of their construction highly visible. Hammonds pleads for black women writers and critics to go beyond an exploration of distorted sexualities from the past. She believes it is necessary to explore contemporary manifestations of black female sexuality inside texts:

...in overturning the "politics of silence" the goal cannot be merely to be seen: visibility in and of itself does not erase a history of silence nor does it challenge the structure of power and domination, symbolic and material, that determines what can and cannot be seen. The goal should be to develop a "politics of articulation." This politics would build on the interrogation of what makes it possible for black women to speak and act (Hammonds 141).

Damali and Jessica embrace their sensuality as they explore their sexual agency as lovers in complicated, heterosexual relationships. It is necessary to note that neither writer's construction of black female sexuality is better than the other's sexuality. Each one occupies different areas of the spectrum of representations that Hammonds urgently recommends in the articulation of black female sexuality. Due's works possess a certain subtlety that Banks wholeheartedly eschews.

Tananarive Due embraces the task of articulating black women's sexuality as a notable but understated facet of her construction of Jessica Wolde. Due steadily acknowledges the strength of the sexual attraction between Jessica and her husband, David. In the first work of the trilogy, the couple has a healthy sex life that is alluded to and explored in a brief and restrained love scene. Jessica also reminisces about her eager participation in the rituals of seduction that informed their first sexual encounter (Due My Soul to Keep). Yet, even after the hell Jessica and David have gone through as a couple in the first book (David's unintentional killing of their daughter, Kira, coupled with the discovery of his numerous betrayals and web of lies), Jessica is still moved by her visceral attraction to him: "The raw beauty 
in his clay-brown face stung her, nearly bringing tears to her eyes" (Due The Living Blood 260). Due's acknowledgement of Jessica's sexuality through subtle nuance of the couple's experiences and feelings for each other seem almost mute in comparison to the explicit sexuality that permeates the works of L.A. Banks.

L.A. Banks' previous experiences as a writer of contemporary black romances heavily influence the sustained explorations of the sexuality of her series' main character, Damali Richards. ${ }^{4}$ The series begins with a heavy attraction between Damali and her eventual mate, Carlos Rivera. They consummate their relationship in the third novel, The Hunted (2004). The juxtaposition with the subtlety of Due is appealing. The first sex scene between Damali and Carlos is not a fond memory; it is present, visceral, sensual, and incredibly descriptive, for it spans almost thirty pages. Banks is thorough in presenting the multiple expressions of black female sexuality that is capable in a tempestuous relationship between two passionate young people fighting against evil with paranormal powers. Their sex life mirrors the nature of their sometimes-rocky relationship. Damali's sexuality fluctuates and matures as it mirrors the couple's supernatural ability to project onto the astral plane (Banks The Awakening), anger and frustration with each other (Banks The Forbidden), and even their vampiric tendencies (Banks The Bitten). Banks purposely presents sex as an ongoing and prominent facet of Damali's life throughout her growth as a Neteru and through the roles of girlfriend, lover, wife, and, ultimately, mother. Banks' sex positive black female characters present sex as a natural and healthy part of life.

Banks also proves that the exploration of black female sexuality is far from a young endeavor. Marlene Stone, Damali's spiritual mentor/othermother, spends the majority of The Hunted stuck in a love triangle between her current tactical psychic lover, Shabazz and her Brazilian shapeshifting former lover, Kamal. Banks portrays Marlene as a conscious woman enjoying her fifties who can still be rocked by a deep attraction to a former lover. Marlene is desirable, knowledgeable and sensual as she hints at a past filled with loves as tempestuous as what Damali is currently experiencing with Carlos. Banks and Due possess an agency in reinterpreting vampires to successfully answer Evelynn Hammonds' call for an articulation of black female sexuality that is not only visible, but is also enjoyable and nuanced. 
Each writer also places a specific focus on the importance of their lead female characters' body, revisiting a historic lack of agency possessed by black women as their bodies were continuously defined as non-entities. In her article, "The Body Politic: Black Female Sexuality and the Nineteenth-Century Euro-American Imagination,” Beverly Guy-Sheftall insists that historically, black women were defined by their inability to have agency over their own bodies, "it was the exploitation of the black woman's body-her vagina, her uterus, her breasts, and also her muscle-that set her apart from white women and was the mark of her vulnerability" (Guy-Sheftall 30). Banks and Due rewrite the historical realities of black female bodies by creating characters that find and exert agency over their bodies. Admittedly, both fictional characters come to their powers through forces beyond their control: Damali is chosen as the Neteru by divine blessing and Jessica has the living blood forced upon her by her husband David. But within these circumstances, each woman finds agency and begins to write her own rules in using her body to serve herself and her community at large. Banks and Due use vampire horror to write a "resistance narrative [that] portrays their courageous quest for the integrity of [black women's] bodies which have historically been displayed, beaten, stripped, bruised, penetrated, overworked, raped and even lynched" (Guy-Sheftall 31).

Banks begins her rewriting of the history of black women's bodies by physically branding Damali as the Neteru. Historically, the branding of slaves signified ownership by another, a physical marker of the lack of agency the black woman had over her body. But, Damali's tattoo is a mark of the divine for she has been chosen by the Most High to lead the fight against evil. Her tattoo is made of silver, which signifies the silver (poisonous to vampires) in her blood and the precious cargo of God she embodies. The most interesting aspect of Damali's Sankofa tattoo is that it marks her as both protector and as the protected. She leads the charge against the insidious blight of vampires in the world, a metaphor L.A. Banks explicitly explains in the following way: "Vampires-because they suck blood, [are] a metaphor; they suck the lifeblood out of the community as predators, and really have no sense of mortality or moral compass" (Pough 165). Damali protects the innocent bystanders while recruiting/recognizing more soldiers for her divine army. As the leader of her team, Damali is often the first on the field of battle and the creator/researcher of the battle plan. It is Damali who delivers the killing blow to Fallon Nuit, further desecrating 
his body by saying a prayer over his dying, demonic form (Banks The Awakening 285). The army of 144,000 divine soldiers, also known as guardians, who sacrifice life, limb, and sanity so that Damali may continue her divine mission, specifically protects her, and the tattoo also marks Damali as protected.

Damali's body is a weapon. She possesses enhanced physical senses including hearing, smelling, tactile, and psychic abilities that make her a better hunter and fighter of the undead:

Her eyes didn't even have to strain in the dark. Each creature she brought down, the sharper her senses became. It was exhilarating, a rush, and created a hunger to push forward. She was out of the team's circle, had left the ground with a hurling kick to stun a beast before she put her foot on its chest, then planted the sword in the center of its ugly flat skull (Banks The Awakening 268).

Her sword and dagger, Madame Isis and Baby Isis become extensions of her very person and aid as she uses her supernatural powers in service of the larger community. In every novel, a guardian sacrifices his or her life so that Damali may live and continue her divine mission. This is most evident in the construction of her partner, Carlos. Carlos has three distinct deaths over the course of the twelve books and continuously places himself and his team in harm's way to physically rescue and protect Damali (Banks The Bitten; Banks The Damned; Banks The Awakening). This is an urgent rereading of black womanhood because black women generally lack protection within the Western patriarchy. The portrayal of Black women is often as protectors, and as the strongblackwoman, but Banks uses vampire horror fiction to complicate this stereotype, never privileging one over the other and allowing Damali's strength under both circumstances to worry the archaic lines that have historically constructed black womanhood.

Jessica Jacobs-Wolde also risks the safety and well being of her family to aid and improve her community. Jessica, though on the run in a foreign country, begins to control her body with a newly discovered sense of agency. She realizes that she has the gift of life literally running through her veins: "Because of the blood, everything just felt different to her now. Cold was cooler, hot was hotter. Sensations felt more acute. Even food tasted different...She could even taste the air now. The air tasted slightly bitter from the dust..." (Due The Living Blood 57). It is with this 
newly found power that Jessica makes arrangements with her physician sister to begin sharing her blood, the very essence of her body with those who need it: "But if the neighbor's child was really sick...Alex gave her a shot of their serum. After that the child got better" (Due The Living Blood 58). Due specifically juxtaposes the secret power of the men of the Colony of Immortals and Jessica's willingness to share those powers with those in need of power. Jessica, her sister Alex, and her daughter Fana live in hiding, but they still make a commitment to help those in need, that is, their adopted community. Their gift must be doled out in secret, so as not to draw attention to their special abilities, but Jessica remains committed to aiding her neighbors, not out of any need for reverence, but because of a necessity to serve. Due speaks to this commitment to community, when she writes, "I do like to use any opportunity I can to encourage Black American readers to look beyond the confines of their own attitudes and existence. We are part of a grand Diaspora, and while we may have more financially than our brothers and sisters elsewhere, there are some fundamental ways in which we have been robbed..." (Due The Living Blood 155). Thus, Due empowers Jessica with a commitment to help her community with the gifts she bears from her body.

Still, the most important gift Jessica receives from David is that of her daughter, Fana. This is another instance of empowerment for Jessica, which has the potential to aid the world community, for Fana is incredibly powerful. As the offspring of two immortals, Fana not only possesses the immortality of Jessica and David, she possesses immense psychic abilities that include control of the weather, communication across continents and consciousness, and power over life and death. Fana is a revolutionary being who possesses the possibility to do the world great harm or great good. The influence of Jessica, her family, and the community at large will shape who and what Fana will become. Jessica often asks of herself and others, "How do you raise a goddess?” (Due The Living Blood 498).

Yet, Jessica has protection as she protects others in her surroundings. Alexis and the Botswanan nurse, Bea, fiercely protect Jessica from a crazed male intruder, sick with AIDS and determined to find the lady with the cure. Bea is physically assaulted by the man as Alexis attempts to herd Jessica to the back of the house (Due The Living Blood). In both novels, David's central concern is protecting his family, most especially Jessica, from the violent and hateful onslaught from the Brotherhood as 
consequences for his disobedience (Due My Soul to Keep; Due The Living Blood). He is pursued, hunted and attacked in Florida during his battles with the Brotherhood (Due My Soul to Keep). He is burned alive at the onset of the series' second novel by those Immortals who consider him a heretic, an attack which forces him to a period of painstakingly slow healing (Due The Living Blood). The most telling example of protection in Due's texts is Fana's protection and concern for her mother, Jessica. Early in the novel, Fana enters her mother's mind and erases her memories of her older sister, Kira, who David murdered in the first novel. This erasure is an early sign of the significance and breadth of Fana's powers. Fana removes Kira from Jessica's mind because: "She hurts you. It's more better with her gone, right?" (Due The Living Blood 104). Later, Fana is the first to successfully kill one of the Immortal brothers, Kaleb, through a graphic act of exsanguination. This occurs only after Kaleb voices his regret at not killing Jessica, that "mortal bitch" by "yank[ing] her mutated child from the womb and roast[ing] it alive" (Due The Living Blood 310).

Due and Banks are creating characters that are continuing the community work that black women have been doing for centuries; but, both writers use the realm of horror fiction to reimagine and complicate previous caricatures of the black woman and her body. The authors craft black female characters that are multifaceted in their sensuality, and in their sense of purpose and their obligations to their communities. For as hard as these women love and as much as they sacrifice, their families and communities reciprocate that much more, enhancing and expounding the limits of love and protection expressed by and for the black women of speculative fiction.

\section{Works Cited}

Banks, L.A. The Awakening. A Vampire Huntress Legend. New York: St. Martin's Paperbacks, 2003. Print.

---. The Bitten. New York: St. Martin's Griffin, 2005. Print.

---. The Damned. A Vampire Huntress Legend. New York: St. Martin's Griffin, 2006. Print.

---. The Forbidden. A Vampire Huntress Legend. New York: St. Martin's Griffin, 2005. Print.

Boyce-Davies, Carol. Black Women, Writing and Identity: 
Migrations of the Subject. New York: Routledge, 1994.

Print.

Clover, Carol J. . "'Her Body, Himself: Gender in the Slasher Film'." Feminist Film Theory: A Reader. Ed. Thornham, Sue. New York: New York University Press, 1999. Print.

Creed, Barbara. "'Horror and the Monstrous-Feminine: An Imaginary Abjection." Feminist Film Theory: A Reader. Ed. Thornham, Sue. New York: New York University Press, 1999. Print.

Due, Tananarive. The Living Blood. New York: Washington Square Press, 2001. Print.

---. My Soul to Keep. New York: Eos, 1997. Print.

Guy-Sheftall, Beverly. "The Body Politic: Black Female Sexuality and the Nineteenth-Century Euro-American Imagination." Skin Deep, Spirit Strong: The Black Female Body in American Culture. Ed. WallaceSanders, Kimberly. Ann Arbor: The University of Michigan Press, 2002. Print.

Hammonds, Evelynn. "Black (W)Holes and the Geometry of Black Female Sexuality." Differences: A Journal of Feminist Cultural Studies 9.3 (1994): 31-45. Print.

hooks, bell. "The Oppositional Gaze: Black Female Spectators." Feminist Film Theory: A Reader. Ed. Thornham, Sue. New York: New York University Press, 1999. Print.

Hutchings, Peter. The Horror Film. Inside Film. Harlow, England ; New York: Pearson Longman, 2004. Print.

Morgan, Joan. When Chickenheads Come Home to Roost: My Life as a Hip-Hop Feminist. New York: Simon \& Schuster, 1999. Print.

Mulvey, Laura. "Visual Pleasure and Narrative Cinema." Screen 16.3 (1975): 6-18. Print.

Pough, Gwendolyn D. "Interview with L.A. Bank; Spring 2004; May 1, 2004." Femspec 6.1 (2005). Print.

Pough, Gwendolyn D., and Yolanda Hood. "Speculative Black Women: Magic, Fantasy, and the Supernatural." Femspec 6.1 (2005): ix. Print.

Spillers, Hortense. "Interstices: A Small Drama of Words." Pleasure and Danger: Exploring Female Sexuality. Ed. Vance, Carole S. Boston: Routledge, 1984. Print.

Stevenson, John Allen. "A Vampire in the Mirror: The 
Sexuality of Dracula." PMLA 103.2 (1988): 139-49.

Print.

Wall, Cheryl A. Worrying the Line: Black Women Writers, Lineage, and Literary Tradition. Chapel Hill, NC: University of North Carolina Press, 2005. Print. 


\section{Endnotes}

${ }^{1}$ I begin this talk with film theory to draw attention to the lack of black women creators, not just of film as a whole, but specifically within the genre of the horror film. I posit that Due, Banks, Gomez, and other horror fiction writers like them must find their gaze in the written word, for the construction of black female characters within this genre fail to exist multiplicitously in the visual realm.

${ }^{2}$ hooks is in effect "talking back" to many film theorists in this text. Most especially, she addresses Laura Mulvey's position that women are often put on display in film for a penetrative male gaze. See Laura Mulvey, "Visual Pleasure and Narrative Cinema," Screen 16.3 (1975).

3 Pough expands upon this to include speculative fiction as a whole.

${ }^{5}$ L.A. Banks is a nom de plume for Leslie Esdaile Banks. Ms. Banks writes under multiple names that depend on the genre she is exploring. L.A. Banks is reserved for her paranormal/supernatural thrillers, Leslie Esdaile and Leslie E. Banks serves for her romance novels and finally, she uses Leslie Esdaile Banks for her crime/suspense novels. 